\title{
Kwaliteit van accountantsdiensten in de perceptie van de gebruiker
}

\author{
Reportage van een MAB-congres
}

Prof. L.C. van Zutphen

Op 22 november 1994 werden 120 deelnemers namens de redactie van het $M A B$ welkom geheten op een $M A B$-congres gewijd aan het thema 'Kwaliteit van Accountantsdiensten in de perceptie van de gebruiker'. Vele wetenschappers en praktijkmensen hadden zich voor deze studiedag aangemeld en de opkomst kon terecht worden beschouwd als een teken van de grote belangstelling voor dit uitdagende onderwerp.

Een bijzonder woord van welkom gold de inleiders van deze dag Prof. Dr. F.G.R. Pieters van de Katholieke Universiteit Brabant, Prof. Dr. P.S.H. Leeflang en de heer Drs. G.B.W. Willenborg van de Rijksuniversiteit Groningen, Prof. Joseph V. Carcello van de University of Tennessee en de heer Drs. C. Griffioen RA, lid van de Raad van Bestuur en Chief Financial Officer van KPN.

Tijdens de middagzitting werden de inleidingen en onderzoeksresultaten bediscussieerd door een forum bestaande uit de heren Prof. Dr. A.J.

Bindenga RA. Voorzitter Raad van Bestuur Moret Ernst \& Young, Mr. F.H.G. de Grave, Wethouder van Financiën Gemeente Amsterdam, Drs. C. Griffioen RA, Drs. B.F. Baron van Ittersum, Voorzitter Vereniging voor de Effectenhandel. Drs. G. Izeboud RA, Lid Raad van Bestuur Coopers \& Lybrand, Drs. T. de Swaan, Directeur van de Nederlandsche Bank en Prof. Drs. J. Weitenberg, Algemeen Directeur Noordelijk Christelijk Werkgeversverbond.

Het voorzitterschap van het congres was in handen van de schrijver van dit artikel.

Het congres was aangekondigd als een ontmoeting en samenspraak tussen wetenschapsbeoefenatren en functionarissen uit de praktijk. Daarmee trok de redactie de lijn door die in het verleden al werd ingezet. Het is immers voor onderzoekers van groot belang om van tijd tot tijd de uitkomsten van hun wetenschappelijke research te toetsen aan de ideeën en de opvattingen van degenen die dagelijks actief zijn in de 'frischfröhliche Praxis'. Omgekeerd is het evenzeer van groot belang dat de praktijkbeoefenaren profiteren van richtinggevende conclusies en aanbevelingen uit voor hen relevant wetenschappelijk onderzoek. Aldus ontstaat een setting van wederzijds voordeel.

Kwaliteit van accountantsdiensten vanuit de optiek van de gebruiker; waarom werd juist dit thema gekozen? De redenen zijn simpel en voor de hand liggend. De issue komt van alle kanten op ons af.

Kwaliteitszorg en kwaliteitsmanagement worden terecht beschouwd als vitale bedrijfsfuncties en als belangrijke motoren voor succesvol opereren van ondernemingen en instellingen, nu en in de toekomst. Deze kwaliteitsfuncties zijn daarom ook van grote betekenis voor de opwaartse ontwikkeling van ons land.

In de TNO-beleidsstudie De Economische Kracht van Nederland', waarin Porter's diamant als benadering van de toekomstige concurrentiekracht wordt uitgewerkt, komt ten aanzien van ondernemingen de aanbeveling voor dat bij een innovatiegeoriënteerde economie eigenlijk alles

Prof. L.C. van Zutphen RA is hoogleraar Accountantscontrole aan de Vrije Universiteit te Amsterdam. Daarnaast is hij voorzitter van het Limperg Instituut en lid van de Orde van Organisatiekundigen en -Adviseurs. 
draait om continue verbetering van de eindprodukten met een focus op kwaliteit en differentiatie.

Accountants die hun controle- en adviesdiensten aanbieden op de markt. binnen organisaties of binnen de overheid doen er goed aan in deze beweging mee te gaan - of beter nog - erop te anticiperen. Vele accountantskantoren en -diensten hebben deze boodschap begrepen en besteden grote aandacht aan hun systemen van kwaliteitszorg.

Kwaliteit van accountantsdiensten in de perceptie van de gebruiker. In de titel gaan al drie begrippen schuil die om een nadere invulling vragen, te weten 'accountantsdiensten', 'kwaliteit van accountantsdiensten' en 'de perceptie van de gebruiker'.

Ter nadere introductie volgen hieronder enkele algemene opmerkingen.

\section{Accountantsdiensten}

Wat zijn accountantsdiensten? Welke diensten bieden accountantskantoren en -diensten aan? Ik wil volstaan met een grove aanduiding van het door accountants aangeboden dienstenpakket, ten dele als gevolg van een wettelijke verplichting.

In de discussienota Kwaliteit van mei 1992 van het NIVRA ${ }^{2}$ wordt onderscheid gemaakt tussen diensten die op derden gericht zijn en diensten die uitsluitend gericht zijn op opdrachtgevers.

Bij diensten voor derden ligt het accent op de controle en daaraan verwante opdrachten.

In de NIVRA-richtlijn voor de Accountantscontrole $0.01{ }^{3}$ wordt deze kernactiviteit als volgt getypeerd:

'De inschakeling van de accountant bij (financiële) informatie wekt vertrouwen op bij de gebruikers van die informatie. De accountant voegt op grond van zijn werkzaamheden geloofwaardigheid toe of, anders gezegd hij verschaft een bepaalde mate van zekerheid aan de gebruiker met betrekking tot de betrouwbaarheid van de informatie.'

Die mate van zekerheid is afhankelijk van de aard en de omvang van de verrichte werkzaamheden of anders gezegd de intensiteit waarmee gecontroleerd is.
Bij beoordelingsopdrachten en overeengekomen specifieke werkzaamheden is er sprake van een andere mate van zekerheid dan bij de zogeheten controle-opdracht.

De produkten die uit dergelijke controlewerkzaamheden voortkomen zijn accountantsverklaringen en mededelingen (al of niet te publiceren), managementletters, rapporten, verslagen e.d.

Bij diensten uitsluitend aan opdrachtgevers is het moeilijker om van een algemeen kader te spreken. Het kan daarbij gaan om bijzondere onderzoeken als aandelen-waarderingen. due-diligenceonderzoek, vaststelling verzekerd belang, oplaagcontrole. branden bedrijfsschade-onderzoek e.d.

Maar vaak gaat het ook om adviezen. Adviezen die ten dele binnen de deskundigheid van accountants vallen, bijvoorbeeld op het terrein van de administratieve organisatie en interne controle en die adviezen die vanuit het samenwerkingsverband, bijvoorbeeld de multidisciplinaire maatschap, worden aangeboden (management consultancy, belastingadviezen, EDP-audit en subsidieadvies).

Bij dit alles komt nog dat het dienstenpakket van accountantskantoren en in mindere mate ook bij interne accountantsorganen bij voortduring in beweging is als een reactie of anticipatie op de behoeften in de markt of binnen het bedrijf en ter handhaving of verbetering van de eigen (interne) marktpositie.

De groeiende behoefte aan quality-assurance op velerlei terreinen wordt ook opgepakt door accountantskantoren. Daarbij kan worden gedacht aan kwaliteitsaudits als het gaat om milieuzorgsystemen, fraudepreventie, internal control, informatiebeveiliging e.d.

\section{Kwaliteit van accountantsdiensten}

Wat is kwaliteit of scherper, wat moet worden verstaan onder kwaliteit van accountantsdiensten?

Er zijn schrijvers die menen dat kwaliteit te isoleren is in een eenvoudige nogal technisch aandoende definitie. Bijvoorbeeld: 'conformance to requirements' (Crosby).

Sommige beroepsbeoefenaren kunnen daar overigens vanuit hun specifieke functie best mee uit de voeten, zoals software-ontwikkelaars. Hun opdracht is computerprogramma's te ontwikkelen die exact voldoen aan vooraf gespecificeerde gebruikerseisen. 
Maar wie het $M A B$-themanummer over $\mathrm{kwaliteit}$ van dienstverlening heeft gelezen beseft dat kwaliteit een meerdimensionaal begrip is en moet worden bezien vanuit meerdere perspectieven. En dat geldt ook voor de kwaliteit van accountantsdiensten.

Vanuit verschillende werelden wordt er verschillend naar kwaliteit gekeken. Afhankelijk van de optiek spelen ook verschillende sets van eigenschappen of attributen van de accountantsdiensten een rol.

De maten waarmee kwaliteit kan worden gemeten zijn zowel kwantitatief als kwalitatief van aard. Bovendien is kwaliteit van accountantsdiensten niet te verabsoluteren. De kwaliteit van de accountantsverklaring of een ander controleprodukt of advies kan niet los worden gezien van de kwaliteit van de controleprocessen zelve en de daarbij ingezette mensen en middelen. En in het bijzonder ook de kwaliteit van de communicatie tussen accountant en gebruiker verdient de aandacht.

Daarmee krijgt het kwaliteitsprobleem van accountantsdiensten tegelijkertijd een brede scope: diensten, processen, mensen en middelen, en wordt het voor het management een belangrijk onderwerp van afweging en beslissing.

' $K$ waliteit van accountantsdiensten is een moeilijk en multi-interpretabel concept' schrijft Leeflang in zijn proloog tot de eerder genoemde $M A B$-special.

Bij de beoordeling van de kwaliteit van accountantscontrole komen ook moeilijk of niet te beantwoorden vragen naar voren als:

- Is er - ondanks de goedkeurende verklaring toch nog sprake van materiële fouten of onvolkomenheden?

- Is de relatie kwaliteit werk en kwaliteit van het controle resultaat (prestatie-performance ratio) wel acceptabel ?

- Kent de gebruiker de betekenis van het axiomatisch voorbehoud?

- Is de gebruiker op de hoogte van de mogelijkheden en begrenzingen van accountantscontrole?

- Levert de accountant conform de verwachtingen van de afnemer?

Ter afronding volgen hieronder nog enkele opmerkingen over de speciale optiek waaruit op dit congres naar kwaliteit van accountantsdiensten wordt gekeken, te weten vanuit het standpunt van de afnemer.

\section{De perceptie van de gebruiker}

Gebruikers van accountantsdiensten zijn de opdrachtgevers en derden. De laatsten al of niet behorende tot een besloten kring.

De opdrachtgevers zijn in elke concrete situatie duidelijk te identificeren.

Maar het gaat bij gebruikers van accountantsdiensten uiteraard niet alleen om degene die de opdrachtbevestiging heeft getekend, maar in vele gevallen ook om een grote wolk van belanghebbenden en geïnteresseerden.

Bij een vennootschap kan men bijvoorbeeld denken in de eerste lijn aan het financieel-administratieve personeel van de gecontroleerde, de interne accountantsdienst, de afdeling automatisering, de controller e.d.

In de top van de onderneming kunnen als gebruikers worden beschouwd de directie of de raad van bestuur, het audit committee, de raad van commissarissen en de algemene vergadering van aandeelhouders.

Maar daarmee is de reeks van gebruikers bepaald nog niet compleet.

In een door het Limperg Instituut uitgevoerde enquête inzake opvattingen over accountants ${ }^{5}$ worden ook nog genoemd besturen van non-profit organisaties, bankiers en andere functionarissen van financiële instellingen en leden van ondernemingsraden. En aan deze lijst van potentiële gebruikers kunnen zeker nog andere geïnteresseerden in de diensten van de accountant worden toegevoegd.

Men kan daarbij denken aan bestuurders van overheidsorganen, leden van de gemeenteraad, provinciale staten en het parlement, de fiscus, toezichthouders e.d.

Het gaat vandaag om de 'service quality' zoals de cliënten van de accountant deze zien en ervaren.

David Maister hanteert in zijn boek 'Managing the Professional Service Firm'6 daarvoor een simpele formule die hij de wijdse naam gaf van 'The First Law of Service'. Deze formule luidt:

\section{SATISFACTION $=$ PERCEPTION minus EXPECTATION}

Met andere woorden als de gepercipieerde kwaliteit van de service niet voldoet aan de verwachtingen is er sprake van ontevredenheid.

Tenslotte nog een korte introductie van artikelen opgenomen in dit speciale nummer. 
Prof. Leeflang en Drs. Willenborg presenteren in hun artikel 'Het meten van de kwaliteit van de accountantscontrole' belangwekkende resultaten van een telefonisch onderzoek onder 131 middelgrote Nederlandse ondernemingen. Zij filteren de kwaliteitsdimensies uit die van groot belang zijn voor het totaaloordeel over accountantsdiensten en geven concrete aanbevelingen voor de praktijk en voor verder onderzoek.

Prof. Carcello behandelt in zijn artikel de topic 'audit service quality' vanuit een Amerikaanse invalshoek. Zijn bijdrage bevat een survey van belangrijke opvattingen en onderzoeksresultaten uit recente literatuur in de Verenigde Staten.

Bovendien geeft hij een samenvatting van door hem en anderen verricht empirisch onderzoek op dit gebied.

Tijdens het congres presenteerde deze inleider ook resultaten van recent onderzoek in de Verenigde Staten onder de titel 'An Empirical Investigation of Audit Service Quality and the Commodity status of Audits'. Audits Publicatie is echter voorbehouden aan een Amerikaans tijdschrift.

Drs. Griffioens artikel' Kwaliteit van accountantsdiensten; een reflectie uit de ondernemerspraktijk' legt een accent op de attributen van door accountants geleverde diensten die hij als cliënt en (groot)gebruiker belangrijk vindt. De specifieke wensen van de cliënt zijn bepalend voor de levering van een goed produkt. Het artikel bevat zeer behartenswaardige aanbevelingen waarmee de kwaliteit van de dienstverlening kan worden verbeterd en verrijkt.

Prof. Wallage heeft het verslag van de forumdiscussie verzorgd. Een beknopte en evenwichtige weergave van een levendig en ten dele kritisch debat, waarvan kennisneming alleszins de moeite waard is.
Prof. Pieters sprak op het congres over 'De betekenis van professionele kwaliteit': proces en impact! Helaas was de schriftelijke weergave van zijn voordracht ten tijde van het ter perse gaan van dit nummer nog niet gereed.

Naar algemene indruk kan worden teruggezien op een zeer geslaagd MAB-congres.

Het was een boeiende confrontatie van onderzoekers, gebruikers en accountants.

De lezers van het MAB wordt in dit nummer een viertal artikelen aangeboden die een belangrijke toegevoegde waarde kunnen betekenen en met name voor degenen die dagelijks de zorg hebben voor de kwaliteit van accountantsdiensten.

\section{I T E R A T U U R}

1 Dr. D. Jacobs, Drs. P. Boekholt, Prof. Ing. W. Zegveld, (1990), De Economische kracht van Nederland. TNO-beleidsstudie. Stichting Maatschappij en Onderneming.

2 Nederlands Instituut van Registeraccountants, (1992), Discussienota Kwaliteit. Een integrale conceptie voor de kwaliteitsbevordering van dienstverlening door accountants, mei.

3 RADAR Richtliinen voor de accountantscontrole. Algemeen kader met betrekking tot controle en daaraan verwante opdrachten (RC 0.01) juni 1991.

4 Thema-nummer over kwaliteit van dienstverlening, (1993), Maandblad voor Accountancy en Bedriffseconomie, december.

5 Opvattingen over Accountants, (1987), Limperg Instituut. Interuniversitair Instituut voor Accountancy. januari.

6 David H. Maister, (1993), Managing the Professional Service Firm. The Free Press A division of Macmillan Inc. New York. 